\title{
HOUSING POLICY IN SEVEN EUROPEAN COUN- TRIES: THE ROLE OF POLITICS IN HOUSING
}

\author{
Peter Boelhouwer and Harry van der Heijden
}

\section{Introduction}

This contribution outlines the overall policy framework of seven Western European countries. The results are derived from the first part of Housing Systems in Europe: A Comparative Study of Housing Policy (Boelhouwer and Van der Heijden, 1992). An analysis of the most significant approaches to international comparative housing research, as presented in the opening article of this special issue, led to the selection of the areas and issues to be examined here (see Figure 1).

First, we reviewed the background variables that affect housing markets. These include socio-economic, demographic, administrative, and spatial factors as well as physical planning systems.

Part II of the comparative study analyzes the housing systems themselves by means of reviewing past housing policy, describing the organization of the housing market and identifying those involved, and sketching the housing policy envisaged for the 1990s. These housing systems interact with four external factors and determine the objective characteristics of the housing market (though not the housing policy for the 1990s). These objective characteristics include the size of the housing stock, average household size, level of new construction, tenure characteristics of households, and housing costs, for instance.

Given the diversity of subjects to be dealt with, it is not feasible to present all their features in an integral way in this paper. We therefore confine our discussion to the most important general differences and similarities between the countries under review.

In Section 2, we discuss a number of factors exogenous to the housing market, such as demographic change and socio-economic characteristics. We then go on to consider housing construction and building policy in the seven countries. But the most important part of this article elucidates the differences and similarities in the objectives of housing policies. Finally, we offer some general conclusions about the role of politics in housing.

Neth. J. of Housing and the Built Environment, Vol, 8 (1993) No. 4. 
Figure 1 Background factors determining the structure of the housing market

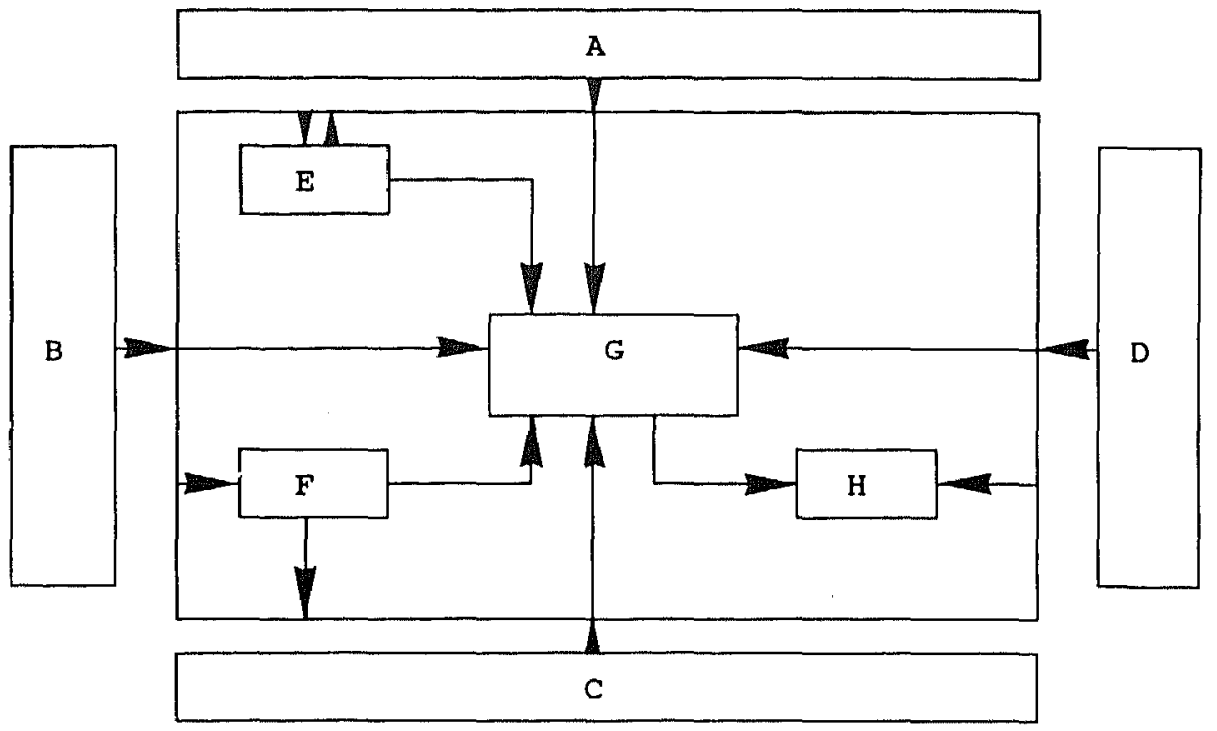

A $=$ socio-economic factors

$\mathrm{B}=$ demographic factors

$\mathrm{C}=$ administrative and legal factors

$\mathrm{D}=$ spatial factors and physical planning systems

$E=$ organization of the housing market and those involved

$\mathrm{F}=$ past housing policy

$\mathrm{G}=$ objective characteristics of the housing market

$\mathrm{H}=$ housing policy during the $1990 \mathrm{~s}$

Source: Boelhouwer and Van der Heijden, 1992, p. 17

\section{Exogenous factors: demographic change and socio-economic limitations}

Housing policy and the objectives that have subsequently been pursued have had a strong bearing on the generation and the characteristics of the present housing market. Yet the development of the housing market was also strongly influenced by a number of factors outside the direct reach of housing policy. These include changes in population size and composition. To a great extent, such changes determine the demand for housing and, consequently, the required level of new construction. Figure 2 shows that the population of the Netherlands grew by $13.6 \%$ between 1977 and 1988 . This was by far the highest rate recorded in any of the seven countries; the next highest was in France (10.3\%). Sweden and Denmark showed more modest rises of $5.1 \%$ and $4.5 \%$ respectively. In Belgium, England, and the FRG the rate of increase was lowest. It is expected that the same pattern of population growth will occur in the future. 
Figure 2 Changes in population size, 1970-1988, as of 1 January $(\%)(1970=$ 100)

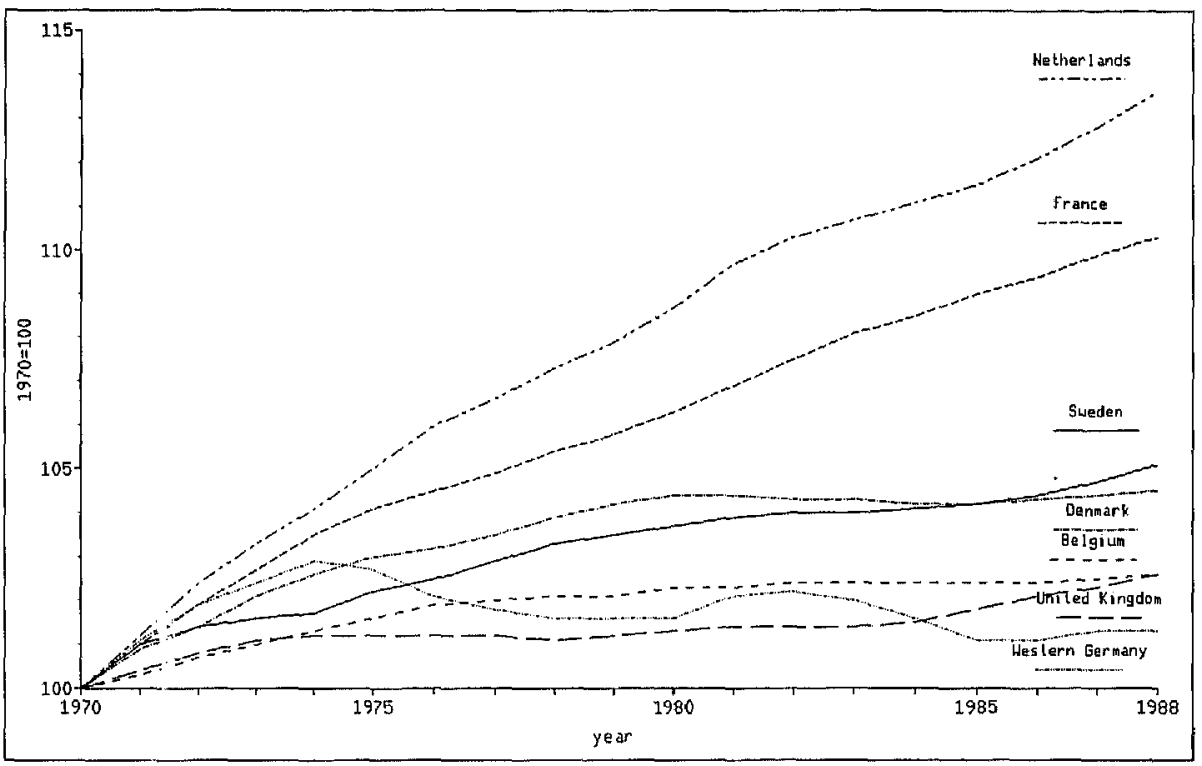

Source: Boelhouwer and Van der Heijden, 1992, p.22

In all the countries included in the study, the number of households increased more than the population. This reflects a preference for smaller households or for living alone. The trend was most evident in the Netherlands, where the reduction in average household size was greatest. The tendency toward smaller households started somewhat later there than in the other countries, but it became marked during the 1970 s and $1980 \mathrm{~s}$.

The above changes suggest that autonomous housing demand was highest in the Netherlands from 1970 to 1987 . During this period, the number of households increased by no less than $48.7 \%$. Other countries also experienced growth, though to a lesser degree. In France, the figure was 29\%; in England, the FRG and Denmark 22\%; while in Belgium and Sweden, it was $15.6 \%$ and $12.1 \%$ respectively. As a consequence of the high rate of population increase in the Netherlands, the growth in per capita Gross National Product (GNP) was relatively small between 1970 and 1988 compared with several other countries (Boelhouwer and Van der Heijden, 1992, p.29).

The growth in number of households during the period 1971-1988 has required significant expansion of the housing stock and thus a considerable degree of new construction in the Netherlands. Accordingly, the greatest expansion in the housing stock had to be shouldered by the country with the lowest 
rate of increase in per capita GNP. In this respect, other countries were in a much more favorable position. Belgium had both the highest rate of growth in per capita GNP and the least need for an autonomous expansion in the housing stock. England and Sweden were also in a somewhat favourable position. While France and Denmark enjoyed lower rates of increase in the number of households, they booked at best only moderate increases in per capita GNP. The FRG is in a less favorable position. The need to provide new housing in the former German Democratic Republic is urgent. Meanwhile, it is imperative to either improve existing housing or simply demolish the worst of it. Moreover, uncertainty remains concerning the number of immigrants from the East. For these reasons, out of the seven countries, the need for new housing construction will probably be the greatest in Germany in the near future.

\section{Housing construction policy}

All the countries reviewed in Part I of the study experienced housing shortages after the Second World War to a large but varying degree. Consequently, in all countries, large-scale housing construction programs were drawn up and the financial means were provided to alleviate this shortage. The governments varied in their approach to this task. By providing supply subsidies, the governments of France and the Netherlands were able to expand the non-profit rented sector considerably (this sector consists predominantly of approved housing associations). A similar development can be observed in Sweden and England, although in these countries local authorities were mainly responsible for the expansion in the non-profit rented sector. The publication of the Housing White Paper in 1953, however, led to a change of emphasis in England: private initiative was strongly encouraged, and local authority housing activities were restricted. Nevertheless, substantial numbers of council houses were built there in the 1950s and 1960s.) In Belgium and Denmark, too, the size of the non-profit rented sector expanded rapidly in the postwar years. To alleviate the serious housing shortage as quickly as possible, the governments of the latter two countries took measures to stimulate the private rented sector immediately after the Second World War.

In the FRG, unlike most other countries, supply subsidies for non-profit rented housing were no longer confined to non-profit housing associations. Rather, they were allocated to anyone who was prepared to meet the conditions attached to the subsidies. The plan to interest private investors in providing nonprofit rented housing has been successful. After government grants to the nonprofit rented sector cease, those owning the properties are able to operate their housing stock as private rented housing. At that point, they are no longer subject to the restrictions imposed on the non-profit rented sector. In the FRG, in addition to the supply subsidies available to the non-profit rented sector, investors in the private rented sector are also eligible for demand subsidies. 
Table 1 Number of dwellings per 1000 population, 1970-1987

\begin{tabular}{lrrrrrrr}
\hline & & & & & & \% growth \\
& 1970 & 1975 & 1980 & 1985 & 1986 & 1987 & $1970-85$ \\
\hline Netherlands & 289 & 320 & 343 & 372 & 377 & 381 & 28.7 \\
FRG & 341 & 383 & 413 & 443 & 448 & - & 29.9 \\
France & $366^{2}$ & 399 & 436 & 449 & 451 & - & 22.7 \\
Belgium & 355 & - & 387 & 405 & - & 406 & 14.1 \\
United Kingdom & 346 & 364 & 383 & 396 & 399 & - & 14.5 \\
Denmark & 353 & $397^{1}$ & 422 & 439 & 445 & 448 & 24.4 \\
Sweden & 394 & $427^{3}$ & $446^{3}$ & $452^{3}$ & - & - & 14.7 \\
\hline 1976 ${ }^{2}$ 1968 ${ }^{3}$ NEI (1989) & \\
Sources: & United Nations, Annual Bulletin of Housing and Building Statistics for Europe, several
\end{tabular}

As a result of these measures taken during the first two decades after the Second World War, the housing stock was expanded considerably (Table 1).

The number of dwellings per 1000 inhabitants was approximately the same in 1970 for all countries. The exception was the Netherlands, where the number of dwellings per 1000 inhabitants was much lower (289) than elsewhere. The figure for Sweden was 394, France 366, Belgium 355, Denmark 353, England 346, and the FRG 341. These variations can largely be explained by the differing rates of population growth; of the seven countries, population growth has been highest in the Netherlands.

Although the number of dwellings per 1000 inhabitants was relatively low in 1970, the housing stock in the Netherlands grew more rapidly during the period 1970-1985 than in the other countries. The rate of increase in the Dutch housing stock between 1970 and 1985 was $42.2 \%$. The corresponding figures for the other countries are significantly lower: France $35.6 \%$, Denmark 31.9\%, the FRG $30.2 \%$, Sweden $21.5 \%$, and England $16.7 \%$. Since the population increase in the Netherlands was greater than in neighboring countries during the period 19701987, however, the increase in number of dwellings per 1000 inhabitants was less spectacular than the growth in the housing stock. Even so, the number of dwellings per 1000 inhabitants increased most in the Netherlands $(28.7 \%)$ and the FRG (29.9\%). Denmark and France followed with $24.4 \%$ and $22.7 \%$ respectively. In Sweden (14.7\%), England (14.5\%), and Belgium (14.1\%), the increase in the number of dwellings per person was lowest.

Demographic change and new housing construction during the period 19701986 have narrowed the gap between the number of dwellings per 1000 inhabitants. In 1986 France had the highest number of dwellings per 1000 inhabitants (451), followed by the FRG (448), Denmark (445), Belgium (406), England (399), and the Netherlands (377).

From 1975 to 1987 , new housing was built that was more expensive than the existing housing stock. As a consequence, the proportion of housing costs in overall consumer expenditure rose during that period. The increase in rentable 
values and the proportion of income spent on rents was highest in the Netherlands (37\%). The figures for other countries are: France (24\%), the FRG (22\%), Denmark (16\%), Sweden (12\%), and the United Kingdom (12\%); the figure for Belgium is not available. Because the calculation of rentable values and proportions of income spent on rents differs among the seven countries, it is unreasonable to try to compare them directly. Housing costs at the micro level are presented in the fourth article in this special issue (Haffner and Menkveld).

An important characteristic of housing, and one about which little information is available, relates to the quality of the housing stock. The only international statistics that are available in this respect concern the housing stock according to year of construction and level of amenities provided. In France, the United Kingdom, Belgium, and Denmark, a relatively large proportion of the housing stock was built before 1945. The Netherlands, the FRG, and Sweden have a relatively young housing stock. If we take the availability of a toilet and of a bath or shower to indicate the level of amenity provided, then housing in Sweden and Denmark ranks highest, followed by the Netherlands.

\section{Housing policy between 1970 and 1990; an overview}

As a number of authors (including McGuire, 1981, and Adriaansens and Priemus, 1986) have already noted, housing policy in these countries has gone through several stages since the Second World War. Roughly four stages may be distinguished. Which stage a particular country is in depends to a great extent on both internal and external factors. These include the perception of the role and tasks of government in general and of the housing targets and objectives of the government in particular.

During the first stage, immediately after the Second World War, there was a high degree of government involvement in housing. Government policies were oriented primarily towards a large-scale housing construction program. The aim was to alleviate the housing shortages caused by the war.

In the second stage, housing policy was concerned with the quality of housing. The new dwellings were more spacious, had more rooms, and the level of amenity provided was higher. Furthermore, in many countries this stage was characterized by the switch from new construction to the improvement and maintenance of the existing buildings. The quality of the housing stock was improved by slum clearance or by renovating substandard dwellings.

In the transition from the second to the third stages, market influences played an increasing role. In many cases, the concept that each household ought to be accommodated according to its needs was abandoned. Instead, housing provision increasingly came to depend on effective demand.

In the third stage, much attention was given to the problems of distribution. Because of the decline in public expenditure, the suitability and effectiveness of the instruments of a government's housing policy were carefully scrutinized. There was widespread reduction in overall subsidies, like general supply sub- 
sidies for new construction, and the extension of demand subsidies. As a result, the position of less well-off groups in particular was given greater emphasis in housing policy. In this third stage, one finds a general decrease in the level of new housing construction.

Finally, in a number of countries one can discern a fourth stage, which is characterized by housing shortages. These take the form of an absolute shortage and an insufficient supply of affordable housing for the less well-off.

It is possible that a country may pass through more than one stage concurrently, since the stages are determined by different external factors. Figure 3 indicates when these stages were characteristic of the seven countries and when, if at all, they ceased to be so. The dating of the beginning and the end of these stages is based as much as possible on the policy objectives formulated by governments.

Figure 3 reveals that the various stages in the development of housing policy did not coincide in all seven countries. Evidently, the stages do not necessarily occur successively. Housing policy in the Netherlands, for instance, can still be characterized in terms of the first stage of the model outlined above, while stages two and three have already commenced. In a number of other countries (the FRG and Denmark), the third stage started before housing policy explicitly emphasized the need for improvements in the quality of the housing stock. Furthermore, since the beginning of the 1990s, the situation has changed dramatically in Sweden. Under the privatization policy of the social democratic government, housing costs for most households increased by $20 \%$ in 1991. After the general elections in September of that year, a new government was formed by a bourgeois coalition. The government wants to reduce the general subsidy even more than was agreed in 1991. It shows a strong interest in deregulation of planning. Moreover, it is interested in making conversion of rental tenure to cooperatively owned tenure easier and applicable even to the public rental housing sector (Siksiö, 1993).

As we have already suggested, the beginning and the possible end of the various stages in housing policy are determined not only by exogenous factors. The timeframe is also a reflection of the role played by governments in general and in the field of housing in particular. Consequently, policy stages are also demarcated by the way governments react to changing external factors (economic crisis or equilibrium). This is especially relevant to the second and third stages. One might assume that governments with similar ideologies would have reacted in similar ways to changing circumstances. This assumption is discussed in more detail below when the housing policies of the seven countries are reviewed.

In seeking to determine the influence of political ideology, we must consider the political complexion of the governments in power in the seven countries. For the sake of comparison, we shall make a distinction between parties on the right and those on the left of the political spectrum. Conservatives may be allocated to the former, and socialist, communist, and social democratic parties to the latter. The Christian Democrats (a powerful force in Belgium, the FRG, and the Netherlands) generally occupy a position in the middle of the road. Liberal parties defy 
Figure 3 General development trends in housing policy, 1945-1990

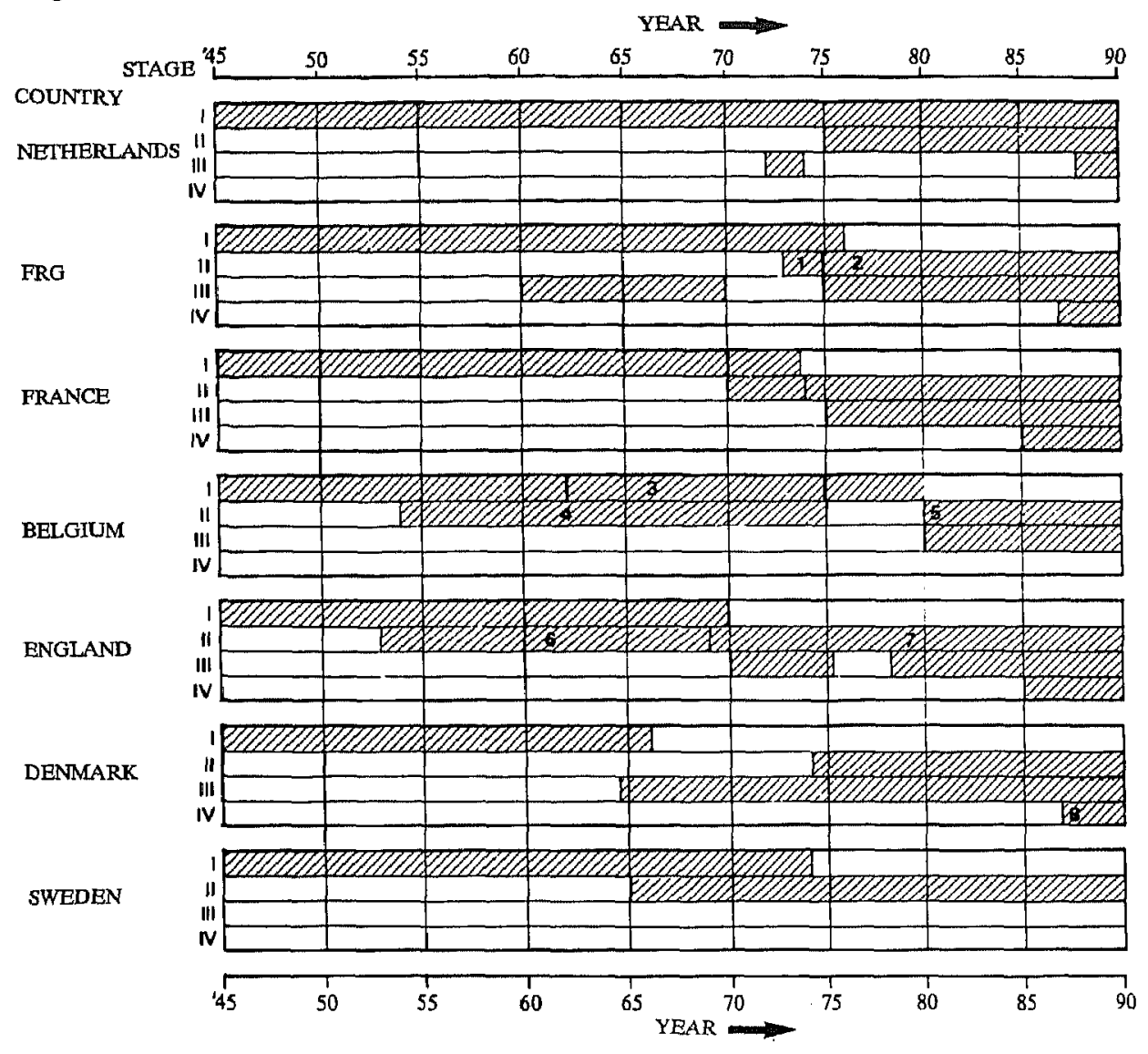

I High degree of government involvement, particularly in order to alleviate housing shortages.

II Greater emphasis on housing quality.

III Greater emphasis on problems of housing distribution and targeting specific groups, and the withdrawal of the state in favor of the private sector.

IV Reappearance of quantitative and/or qualitative housing shortages; increasing state involvement.

1) Improvement in the quality of new housing construction.

2) Improvement in the quality of the housing stock.

3) Housing construction as an element of economic policy.

4,6) Improvement in the quality of the stock by slum clearance program and substitution of new construction.

5) Emphasis on housing improvements in addition to slum clearance.

7) Emphasis on maintenance and improvement instead of slum clearance.

8) Housing shortages, mainly caused by the collapse of the owner-occupied sector, and consequently a significant increase in demand for (cheap) rented housing.

Source: Boelhouwer and Van der Heijden, 1992, p. 273 
easy categorization. For instance, the Liberal Party in the Netherlands is somewhat similar to the Conservative Party in England, while the Liberal Party in England can be located somewhat to the left of the political center. One may also discern substantial variations across countries between parties with the same broad political background. The Labour Party in England, for example, has advocated much more radical social and economic policies than the SPD in the FRG.

Once we have determined the political complexion of the governments, we can move the analysis forward. We can then ascertain if the characteristics often associated with the policies that are supported by various political groups actually correspond to the housing policies they advocate. Alternatively, we can find out if ideology is a less significant determinant of housing policy.

It is often stated that parties on the political right favor a free market in which state involvement is limited. In the case of housing, this means deregulation and support for the owner-occupied and private rented sectors. It also means limited aid to the non-profit rented sector and a role for the latter that is restricted to housing the weakest members of society.

The received wisdom is that parties to the left of the political center emphasize the responsibilities and functions of local and central government. As in the postwar period, the government considers itself responsible for alleviating housing shortages. Thus, government can be expected to achieve a more equitable distribution of available housing resources.

Our description of the housing policies advocated by the major political blocs is a useful basis for further analysis. We now move on to consider the political complexion of the governments in the countries under review. This allows us to compare the housing policies they have introduced.

\section{Housing policy in the 1970s}

Most countries in the 1970s had a government in which a social democratic or a socialist party was represented. This is true of the FRG (1970-1982), England (1974-1979) Denmark (up to 1982), Sweden (up to 1976), Belgium (1970-1974 and 1977-1980), and the Netherlands (1973-1977). In the case of Belgium and the Netherlands, the Christian Democrats have been in every government since the Second World War. This has ensured a remarkable degree of continuity in policy. In this respect, France is an exceptional case. Giscard d'Estaing's centerright government came into power in 1974 and was replaced by that of the socialist Pierre Mauroy in 1981. The housing policy advocated by the French government was strongly determined by the equilibrium in the housing market and by the economic crises of 1973 and 1979. The developments that had begun as early as the 1960s, which envisioned a gradually diminishing role for the state in housing, continued in the 1970s with greater intensity. For the first time since the Second World War, the government took the official stance that the provision of housing ought to be left as much as possible to the market and that in 
the future the role of government would be a residual one (Pearsall, 1984; Boucher, 1988).

\section{The Netherlands}

The Nota Huur-en Subsidiebeleid (Rent and Subsidy Policy) was presented to the Dutch Parliament in 1974 by a coalition government led by the Social Democratic and Christian Democratic Parties. That report reflected the view, so characteristic of the 1970s, of the capacity of governments to create a better society. The period saw the increasing involvement of central government in many aspects of social and economic life. More specifically, it was considered desirable for central government to take a more active role in the provision of housing. There were a number of motives behind this: the endorsement of the concept of housing as a "merit good" (a consumption good in which citizens ought to be encouraged to invest); and the desire to improve the environment, to ensure a more equitable distribution of resources, and to promote housing development.

After several years of debate, in Huur-en Subsidiebeleid the government opted for a hybrid system of supply and demand subsidies. Supply subsidies were used to ensure that new non-profit rented housing remained within reach of those on average incomes. The government's subsidy policy was broader, however. Subsidies were also provided for improving the residential environment and to increase the range of choice available to all households, including those on low incomes. The latter aim led the government to introduce in 1975 a system of demand subsidies: the Beschikking Individuele Huursubsidie (a system of rent rebates).

The choice of a mixed subsidy system and the involvement of the government in assisting housing construction led to a rapid increase in expenditure on both supply and demand subsidies during the period 1975-1985. The rise in cost was due to high interest rates and of the collapse of the owner-occupied sector (Van der Schaar, 1987; Boelhouwer and Priemus, 1990).

\section{The FRG}

The principal objective of the housing policy enacted by the Social Democrats in the FRG at the beginning of the 1970 s was to enable each household to choose the sort of housing that corresponded to their aspirations and level of income. The rapidly expanding housing construction program had to benefit the population as a whole, not just specific groups. There was also intense debate on the effects of land policy, and a considerable degree of protection for tenants was introduced. This policy ran counter to the policy of deregulation pursued by the Liberals and Christian Democrats in the 1960s. This radical change in housing policy lasted only five years, however. Under the government of Chancellor Schmidt, housing policy once more underwent reform. The background to this was diverse: the oil crisis, which left the government with limited financial resources; the rising costs of construction; and the amount of vacant properties 
in the rented and owner-occupied sectors, which became a feature of the housing market after 1973.

The housing construction program was no longer aimed at the general population. Increasing emphasis was put on assisting the less affluent. Consequently, there was also a switch from supply subsidies to demand subsidies, as well as from new construction to subsidies for improvement (Duvigneau and Schönefeldt, 1989; Leutner et al., 1990).

\section{Belgium}

As in the FRG, postwar housing policy in Belgium was strongly oriented towards encouraging private initiative. The government saw its role as one of providing incentives for the owner-occupied sector, providing rented housing for those households unable to buy their own home, assisting large families (this reflected the considerable influence of the Christian Democrats in government), and the demolition or improvement of substandard housing. This approach was embodied in an official "housing code" published in 1970. Like other countries in Western Europe, Belgium was affected by the first oil crisis in 1973. This crisis had severe repercussions for housing policy. The level of new construction decreased significantly. For many households, it now seemed impossible to become an owner-occupier. In order to ease these problems, a new loans scheme was introduced in 1975 in the non-profit rented sector. In the short term this scheme enabled a relatively large amount of rented housing to be constructed. In the Iong term, however, it led to higher levels of debt and consequent budgetary problems. It also precipitated a decline in the number of new dwellings constructed in the non-profit rented sector (Goossens, 1982; Laurent and Jacques, 1987; De Decker, 1990).

\section{England}

England, too, had a socialist government during the period 1974-1979. At the beginning of the 1970s, however, the Conservatives were in power. The housing policy pursued by the Conservative government was similar to that of the previous Conservative administration (1951-1964): it aimed to promote the private sector and to reduce the role of local authorities. The switch from programs of slum clearance to improvement that had begun under the previous Labour government was continued. Against the background of a deteriorating economic climate, increasing interest rates, rising inflation, and escalating balance of payments problems, a Labour government came to power in 1974. Its housing policy was characterized by a continued emphasis on the importance of housing improvement programs. Tenants were given greater protection. Moreover, the role of local authorities in housing was extended. The attitude of the Labour Party to the roles of the public rented sector and the owner-occupied sector was particularly significant. Even during the 1960s, the construction of public rented housing was considered to be only a temporary solution to the housing problem. Owner-occupation was regarded as the normal form of tenure in the longer term. In 1967 the option mortgage and guarantee scheme was 
introduced to enable low-income groups to buy their own homes. Under this scheme, purchasers who were ineligible for mortgage interest tax relief were able to get a mortgage at a lower rate of interest. During the 1970 s, too, the Labour government sought to expand the owner-occupied sector. In the 1977 discussion document entitled Housing Policy, it was suggested that "owning one's own home is a basic and natural desire." This is not to suggest, however, that the Labour and Conservative governments espoused identical housing policies. On a number of issues - the level of government support for housing, the regulation of the housing market, and the powers allocated to local authorities, for instance - the policy of the Labour government was very different from that pursued by previous Conservative governments (Short, 1982; Smith, 1984).

\section{Denmark}

Like most other Scandinavian countries, Denmark was governed for the entire postwar period by a coalition led by the Social Democratic Party. Yet the housing policy pursued in Denmark may be considered unique in Scandinavia. As early as 1966, the Danish government introduced a series of proposals which, over a period of eight years (1966-1974), aimed at reforming the housing market. The proposals were intended to bring about a deregulated and unsubsidized housing market, free of government intervention, during this transition period. It was hoped that market forces would reduce the difference in rent levels between the private and the non-profit rented sectors. The proposals contained five elements: an increase in rents, a reduction in tax relief for owner-occupiers, a reduction in initial rents in the non-profit rented sector, the introduction of a system of rent rebates, and implementation of measures to limit the rise in construction costs. These objectives were not attained, however, largely because of economic difficulties.

In 1974, therefore, under the leadership of a Social Democrat coalition, a new compromise was reached. The objectives of the new proposals were the same as those in 1966: a reduction in the level of government subsidies and the deregulation of the housing market. One of the key problems was the level of indirect subsidies being made available to the owner-occupied sector through the tax system. It was reckoned that, as a result of the levels of tax relief and the high marginal tax rates, these were twice as high as the level of direct subsidies being paid to the rented sector. Partly as a result of the high levels of indirect subsidies, the size of the owner-occupied sector had increased. By the beginning of the $1980 \mathrm{~s}$, it accounted for around 55\% of the housing stock. This inequality was only reduced in 1987, when reforms were introduced. In order to prevent increasing inequality between owner-occupiers and tenants, the Danish government decided to raise levels of rent rebates gradually until the mid-1980s (Haywood, 1984; Ministry of Housing and Building, 1983, 1984).

\section{Sweden}

The housing policy in Sweden during the 1970s has much in common with the housing policies in the other Scandinavian countries (with the exception of 
Denmark). During the period 1965-1974 an ambitious housing construction program, the "one million dwellings program" was drawn up by the government and successfully completed. The success of this program led to an excess supply of housing in some areas during the 1970s, for the first time since the 1940s. Until then there had been a severe housing shortage, which government policy had seriously sought to alleviate. In 1974, this reversal led to the most fundamental reconsideration of housing policy in Sweden since the 1940s. The overall objective of housing policy had not been to force households into certain sectors of the housing market but to maximize their freedom of choice. Swedish housing policy in the 1970s had much in common therefore with that of the Netherlands, though in Sweden the principles were formulated much more explicitly.

The principles underlying the policy reforms of 1974 can be summarized as follows: that government assistance to the various sectors within the housing market should be equal, that there should be freedom of choice for households with regard to their housing situation, that housing allocation should reflect housing needs, that there should be a fair distribution of housing, and that social amenities and care facilities should be provided in residential areas (Headey, 1978; Nesslein, 1982; Tham, 1987; Lundqvist, 1987).

The housing policies implemented by the various coalition governments that were dominated by socialists and social democrats during the 1970 s demonstrate that housing policy in practice may run counter to what we would expect on the basis of the typology outlined earlier. Only in Sweden, the Netherlands, and the FRG prior to 1975 does housing policy tend to conform to our typology. In all the other countries, the development of housing policy was clearly affected by factors other than those on which our typology is based. These were largely external factors. In almost all countries, there was a housing surplus in particular sectors of the housing market. And almost all Western governments faced acute budgetary difficulties as a result of the oil crises of 1973 and 1979. Ideological considerations played a role too. For instance, in Belgium and England - and, in practice, Denmark too - owner-occupation was considered to be the most desirable form of tenure, even by the socialist and social democratic governments in power during this period. Consequently, the housing policy of these countries during the 1970s was characterized by support for owner-occupiers, a reduction in the level of supply subsidies, and an increase in the level of demand subsidies. In all these countries there was also a switch from programs of new construction to maintenance and improvement of existing housing.

\section{Housing policy in the $1980 \mathrm{~s}$}

In contrast to the 1970s, housing policy in the $1980 \mathrm{~s}$ was, for the most part, formulated by Conservative governments or Conservative-led coalition governments. This was true of the FRG after 1983, Belgium between 1981 and 1988, England after 1979, Denmark after 1982, Sweden between 1976 and 1982, 
France after 1986, and the Netherlands almost continuously after 1977. The housing policies pursued in those countries during the 1980s are described below.

\section{France}

Only in France was there a socialist government in power at the beginning of the 1980s. In May 1981 a new Socialist-Communist government under the premiership of Mauroy came to power. A few months prior to this, François Mitterrand had been elected President. This change of government led to radical policy changes in many fields. Within scarcely a year, a large number of reforms had been carried out. Of these, the decentralization of power and the nationalization of large enterprises and financial institutions received the most attention. In spite of radical changes in a number of policies, there was a continuity in many aspects of the housing policy developed by the previous Liberal administration. Except for the period 1981-1982, the new socialist government also pursued a policy of retrenchment. The underlying principles of the 1977 Housing Act, which aimed at reducing public expenditure and the size of the housing construction program, were no longer adhered to, however. Nevertheless, most of the objectives of the act were retained. Rents were required to reflect market levels, and there was a switch from supply subsidies to demand subsidies. Moreover the government tried to expand the size of the owner-occupied sector (in particular by encouraging those on low incomes to become owner-occupiers) and to promote the improvement of the existing housing stock.

Deregulation of the housing market was begun cautiously towards the end of the socialist government's term of office. It was continued at an accelerated pace in 1986 after the election of a Liberal government headed by Jacques Chirac. The crisis in the French housing market led to a new debate in parliament in the same year. Further steps were taken to deregulate the housing market; rent controls were relaxed, the sale of non-profit rented housing was made easier, and the system of housing finance was reformed. Deregulation and support for the construction industry were accompanied, surprisingly, by considerable levels of public expenditure to increase housing construction in the private rented and owner-occupied sectors (Pearsall, 1984; Boucher, 1988; Hermann, 1988).

\section{The Netherlands}

After the fall of the Den Uyl government in 1977 on the question of land policy, a new period in Dutch housing policy began. In the accord reached between the partners of the Christian-Liberal coalition government in 1978, a number of new policy objectives were outlined. There was agreement to promote owner-occupation (e.g. by selling public rented housing) and to give greater emphasis to limiting the costs of housing development. The possible abolition of supply subsidies was even discussed. However, the government soon faced difficulties in achieving its most important policy objective, the promotion of owner-occupation. This was due to various external factors. After 1978, for instance, the owner-occupied sector stagnated, following a period of significant expansion. At 
the beginning of the 1980s, the owner-occupied sector collapsed completely and average house prices fell from $f 198,800$ in 1978 to $f 138,100$ in 1982.

The Tweede Nota Bouwbeleid (Second Memorandum on Building Policy) denied that it was government's task to set building targets. Nevertheless, pressure from parliament to assist the ailing construction industry caused the government to get involved. Within one year, the housing construction program had been revised no less than five times. As a result of intervention the level of new construction in the non-profit rented sector increased rapidly, and the relationship between the construction of rented housing and that of owneroccupation was transformed. Despite the government's earlier intentions, it was the rented sector that benefited most from government assistance. Consequently, expenditure on supply subsidies increased considerably. Whereas in 1978 the housing program envisioned 32,000 subsidized rented homes and 74,000 owneroccupied dwellings, at the end of 1981 these figures were reversed: at 73,000 and 34,000 respectively.

After an interim government under the premiership of Van Agt, there followed an administration with Lubbers as Prime Minister and Brokx as Secretary of State for Housing. The policy program published in 1983 contained many proposals to cut expenditure on housing. Again they mainly concerned the rented sector, involving higher rents for new rented housing, reducing expenditure on rent rebates, and significant increases in rents for existing housing. Furthermore, the housebuilding program was cut to 102,000 , and the non-profit rented sector took the brunt of these cuts. The owner-occupied sector benefited, not so much by extra subsidies but rather by the absence of the financial burdens introduced in the rented sector. The promotion of owner-occupation again became one of the objectives of government policy. The new administration retained the mixed system of supply and demand subsidies. Within this policy framework, however, important changes were proposed in the building program and the subsidy policy that was begun under Van Agt. These involved in some decentralization, whereby responsibility for housing was delegated to local authorities.

\section{The FRG}

As mentioned earlier, in 1975 the Social Democratic government in the FRG introduced a liberal housing policy. After 1982 this policy was expanded vigorously by the coalition government of the Christian Democrats and Liberals. They believed that the provision of affordable housing for most of the population could best be left to the free market. Regional inequalities would have to be resolved by the regions themselves. The idea of closing the Ministry of Housing was even given serious consideration in the mid-1980s. In 1982 the new government outlined its housing policy: access to the owner-occupied sector was to be made easier for more households, and state regulation of the housing market was to be limited. Its housing policy was market-oriented, but the government relied on demand subsidies (Wohngeld) to protect the least well-off. In order to encourage owner-occupation, the building savings scheme was improved. Despite this, however, the promotion of owner-occupation was no great success in 
Germany. Moreover, since 1982, supply subsidies have been reduced and government financial assistance has increasingly taken the form of demand subsidies.

In conclusion, housing policy in the FRG shifted emphasis between 1983 and 1989 to stress the role of the free market and the decentralization of government responsibility for housing.

\section{Belgium}

The policy pursued in Belgium during the 1980s was hardly different from the course taken in the preceding decade. There continued to be a strong emphasis on private initiative, on promoting home ownership and providing rented housing for those unable to afford their own home, and on the demolition or improvement of substandard housing. A number of regional differences in housing policy emerged, however. In Brussels and the Walloon provinces in the south of the country, the improvement of the housing stock was given greater priority. In Flanders, new housing construction and slum clearance were considered more important. Political responsibility for housing was formally devolved in 1980 . After that there was a dramatic decline in investment in the non-profit rented sector. As a result, almost no non-profit rented housing is currently being built in the Walloon provinces of Belgium, a situation unique in Europe. In absolute terms, too, the number of non-profit rented dwellings is declining, partly as a result of the policy of selling rented housing to sitting tenants.

\section{England}

The Conservative government that came to power in England in 1979 reasserted the importance of a free-market economy in which competition and individual responsibility would bring about economic improvement. In the field of housing, several important measures were announced in the 1980 Housing Act: central government increased its control over local authority housing activities, there was a switch from general supply subsidies to demand subsidies, local authority tenants were given the right to buy their homes at a discount, the preference for improving homes over slum clearance programs and new construction remained, the position of local authority tenants was strengthened, and the private rented sector was stimulated by allowing higher rents and the relaxation of rent controls. As part of its monetary policy, during the period 1979-1983 the government cut public expenditure on housing by no less $40 \%$ in real terms. On the other hand, there was a considerable increase in the level of tax expenditures as a result of the growth of the owner-occupied sector. The level of direct expenditure on housing and indirect expenditure in the form of tax subsidies is currently more or less equal in England (see Papa, 1992).

The Conservative government regarded owner-occupation as the "normal" form of tenure. Those households who were unable or unwilling to be owneroccupiers could take recourse to the private rented sector. The public sector should only be concerned with the provision of housing for special groups, such as the elderly and the disabled. As in Belgium, the public rented sector declined 
in absolute terms in England. Since 1981 the number of sales of local authority dwellings has exceeded (to an increasing extent) the number of new dwellings constructed by local authorities (Kleinman and Whitehead, 1985; Boleat, 1989; Hollander and Schuiling, 1989; Karn, 1988).

\section{Denmark}

In contrast to earlier decades, during the period 1982-1990, Denmark was governed by a series of coalitions consisting of liberal or conservative parties. The most important housing measures introduced by the post-1982 right-wing governments involved, remarkably, reducing the level of indirect subsidies to owner-occupiers. The housing policy of this period was partly a reflection of the political background of the minister of housing. At the beginning of the 1980s the minister of housing was a member of the Center Party, and there was considerable continuity in housing policy. The succeeding liberal minister of housing in 1986 was more concerned with ideological issues, however, such as the role of non-profit rented housing and, among other things, promoting the sale of non-profit rented sector housing.

The economic recession of the early 1980s had major repercussions on the housing market in Denmark. The number of new houses fell from around 34,000 in 1978 (6.6 dwellings per 1000 population) to 21,000 (3.5 dwellings per 1000 population) in 1982. This spectacular decline was much greater than in most other West European countries during this period. In order to cushion this steep fall in the level of new housing construction, a counter-cyclical subsidy policy was pursued for a number of years. Partly in response to pressure from the highly organized construction industry, more resources were allocated to the non-profit rented housing sector after 1982, and maintenance and improvement programs were fostered.

Of the measures introduced by the government, two have had the most effect on the housing market, and in particular on home buyers, over the last few years: the cuts imposed in 1986 and the tax reforms of 1987. Both measures were considered necessary to save the ailing Danish economy and to prevent the national debt ( $f 100$ billion in 1989) from increasing. In the 1980s, the Conservative Party came to realize that part of this deficit was a consequence of the generous way in which owner-occupation had been encouraged by indirect fiscal subsidies (Trollegaard, 1989; Westergard, 1989; Christiansen, 1990).

\section{Sweden}

For the first time since the Second World War, in 1976 the Conservatives and the Center Party came to power in Sweden. Over an uninterrupted period of more than 40 years, the Social Democrats had built up a welfare state strongly regulated by central government. In view of this fact, one might have expected that the new government, like the Conservatives in England at the beginning of the 1980s, would have taken measures to deregulate the housing market and make it more responsive to market forces. In practice, however, this did not occur. In housing, continuity with the past was much more evident than discon- 
tinuity. Indeed, government subsidies for housing increased from 8 billion kronor in 1975 to 26.7 billion kronor in 1982, and increased as a proportion of GNP from $2.7 \%$ in 1976 to $4.1 \%$ in 1982 . This increase was mainly the result of higher expenditure on mortgage interest tax relief and other tax subsidies.

Real efforts to control public spending only took place in 1982, under a coalition government led by the Social Democrats. Under this government the growth in public expenditure was tempered and the proportion of GNP devoted to housing investment declined to $3.2 \%$. Housing policy was again characterized by a commitment to the equal treatment of tenure groups within the housing market (Kemeny, 1987; Marcusson and MacArthur, 1989).

In view of the above, it seems that the housing policies implemented by the various conservative governments during the 1980 s are somewhat at odds with the general description of conservative housing policy offered in the introduction to this section. In the cases of Sweden, the Netherlands, and Belgium, the housing policies of the 1980 s were in essence similar to those pursued during the 1970s (although the intentions behind these policies were sometimes different). The pattern of public expenditure under conservative governments resembled that of their predecessors. In Denmark, at one point public expenditure on housing was increased. At the beginning of the 1980s, as in the Netherlands, new housebuilding programs were drawn up in response to the (international) crisis in the housing market and the subsequent decrease in the level of new construction. At the end of the $1980 \mathrm{~s}$, a number of tax reforms were introduced, along with measures to cut back public expenditure; these triggered a serious crisis in the owner-occupied sector.

In Belgium, too, the housing policy objectives of the government remained fundamentally the same. The number of new non-profit rented dwellings decreased substantially, however. This was the result of attempts to control rising public expenditure (in which the cost of past subsidy commitments played a significant part).

Our general description of the housing policies of conservative governments applies to a certain extent to France, England, and the FRG. These countries have witnessed a general withdrawal by government from the housing market and a greater emphasis on deregulation and market forces.

\section{Concluding remarks}

On the basis of our studies of housing policy in each of the seven countries over the last two decades, it seems safe to conclude that the housing policies of governments both right of center and left of center do not correlate strongly with their ideological stance (Table 2). 
Table 2 The government in power and the direction of state involvment in housing

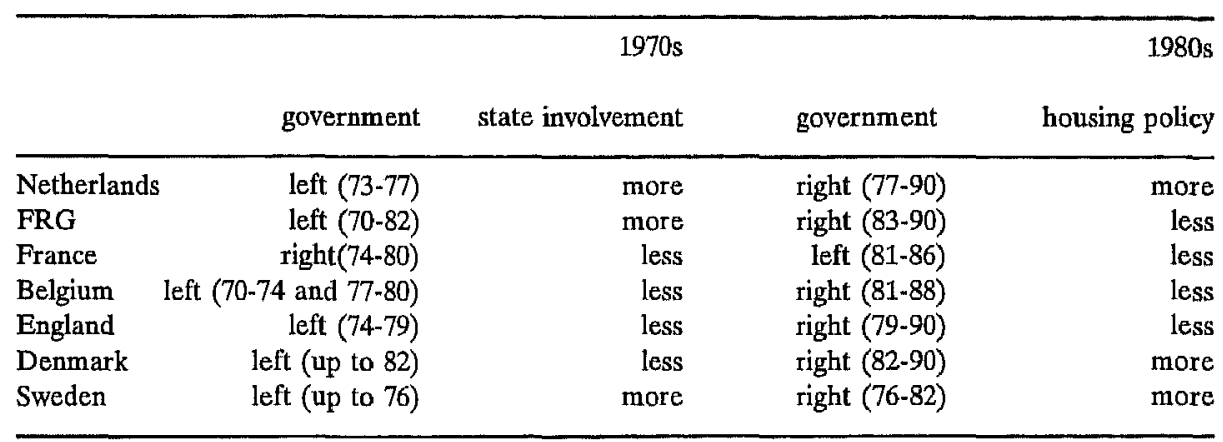

Source: Boelhouwer and Van der Heijden, 1992

In general, of course, there are differences between the objectives and the policies of each political party within each of these countries. The differences in policy between political parties are less marked, however, than the differences between countries. The conditions that prevail within countries, the housing traditions and the structure and characteristics of the housing market (the institutional structure), and electoral considerations (particularly in the case of coalition governments), for example, are much more important in determining the objectives of housing policy and the measures taken as part of that policy. In particular, housing traditions and the institutional structure of the housing market play an important role in this respect. In Belgium and England, for instance, the major political parties have long supported the promotion of owner-occupation. In the FRG the major political parties have attached great importance to the private sector for over 40 years, while in Sweden and the Netherlands the non-profit rented sector has enjoyed the support of various coalition governments. The institutional structure of the housing market also largely determines either the formulation of policy or its successful implementation. In some countries non-profit housing associations exercise a good deal of influence over the political decision-making process. This is either because there may be Members of Parliament on their boards (as in France), or because there is close contact between the political parties and the housing associations. Indeed there is contact between housing corporations and political parties in Sweden and between non-profit housing associations and parties in the Netherlands. Policies which run counter to the interests of these groups (such as the sale of non-profit rented housing) usually have little chance of success.

Furthermore, the housing market is also affected by market conditions and factors outside government control. It is therefore difficult for governments to regulate the housing market in the same way they can influence, education, defense, and health care, for instance. Housing policy is to a much greater extent influenced by more or less autonomous factors. These include the pattern of 
consumer expenditure and consumers' expected incomes, the level of interest rates, regional housing shortages or surpluses, and unexpected immigration flows (as in the FRG). Moreover, housing policy, apart from aiming to achieve specific housing objectives, is also partly determined by the government's overall economic policies. The Netherlands, for instance, owed its economic prosperity during 1950s and the first half of the 1960s in part to a policy of wage restraint. One factor making such a policy feasible was the implementation of stringent rent controls. In Denmark, where a Conservative-led coalition was in power, credit restrictions were introduced as part of a policy to control the national debt. The effect was to make it more difficult to buy a home.

Adriaansens and Priemus (1986, p. 46) drew similar conclusions in their study. They argued that housing policy cannot be understood simply in terms of policy objectives. In practice, policy is the result of a complicated interaction, a compromise between market forces and government interests. It is clear that market forces are a significant factor in determining the pattern of housing policy. But it is also evident that there is some scope for the pursuit of purely political objectives.

\section{References}

Adriaansens, C.A., and H. Priemus (1986), Marges van volkshuisvestingsbeleid, naar een flexibeler juridische vormgeving van een marktgevoelige beleidssektor, 's-Gravenhage: Staatsuitgeverij.

Boelhouwer, P.J., and H. Priemus (1990), "Dutch Housing Policy Realigned", Netherlands Journal of Housing and Environmental Research (5), pp. 105119.

Boelhouwer, P.J., and H.M.H. van der Heijden (1992), Housing Systems in Europe: Part I. A Comparative Study of Housing Policy, (Housing and Urban Policy Studies 1), Delft: Delft University Press.

Boleat, M. (1989), Housing in Britain, London: The Building Societies Association.

Boucher, F. (1988), "France", in Kroes, H., F. Ymkers and A. Mulder (eds.), Between owner-occupation and rented sector, pp. 145-182, De Bilt: NCIV.

Christiansen, H. (1990), "The Danish housing market", Danish Economic Review (74), pp. 16-21.

Decker, P. de (1990), "Housing and Housing Policy in Flanders (Belgium); Confusion on the Eve of a New Decade", Netherlands Journal of Housing and Environmental Research (5), pp. 3-27.

Duvigneau, H.J., and L. Schönefeldt (1989), Social Housing Policy, Federal Republic of Germany, Brussels: COFACE Housing Commission Documents.

Eekhoff, J. (1989), "Wohnungspolitik für die neunziger Jahre, Muß der Staat wieder verstärkt eingreifen?", Gemeinnütziges Wohnungswesen, pp. 371-377. 
Goossens, L. (1982), Het sociaal huisvestingsbeleid in België, Een historischsociologische analyse van de maatschappelijke probleembehandeling op het gebied van het wonen, Dissertation, Katholieke Universiteit te Leuven, Faculteit der Sociale Wetenschappen.

Haywood (1984), "Denmark", in Wynn, M. (ed.), Housing in Europe, pp. 178-197, London: Croom Helm.

Headey, B. (1978), Housing Polic $y$ in the Developed Economy, London: Croom Helm.

Hermann, J. (1988), "Mieterhöhungen von über 100 Prozent, Wohnen in Frankreich", Gemeinnütziges Wohnungswesen, p. 213.

Hollander, E., and D. Schuiling (1989), "De housing act 88 of: Hoe Thatcher de gemeenten verdrijft", Bouw (44), No. 7, pp. 8-11.

Karn, V. (1988), "The baby and the bathwater?, Housing Reform 1988", Housing Review (37), May-June, pp. 85-89.

Kemeny, J. (1987), "Sweden; Social Housing at the Crossroads", Roof, September/October.

Kleinman, M., and C. Whitehead (1985), "The Geography of Private Renting", Housing Review (34), pp. 13-16.

Laurent, L., and M. Jacques (1987), Social Housing Policy, Belgium, Brussels: COFACE Housing Commission Documents.

Leutner, B., K. Domscheit, C. Dietzsch et al. (1990), Wohnungspolitik nach dem 2. weltkrieg, Bestandsaufname und kritische Analyse der Instrumente, Hamburg: GEWOS.

Lundqvist, L.J. (1987), "Sweden's Housing Policy and the Quest for Tenure Neutrality, an Evaluation of Goal Achievment", Scandinavian Housing and Planning Research (4), pp. 119-133.

Marcusson, M., and I. MacArthur (1989), Distributional Aspects of Housing and Taxation Policies in Sweden, (Swedish National Monograph), Karlskrona: Boverket.

McGuire, C.C. (1981), International Housing Policies, a Comparative Analysis, Lexington: Lexington Books.

Ministry of Housing and Building Denmark (1983), Rent Policy in Denmark, Copenhagen: Ministry of Housing.

Ministry of Housing and Building Denmark (1984), Financing of Housing in Denmark, Copenhagen: Ministry of Housing and Building.

MVROM (1989), Nota Volkshuisvesting in de Jaren Negentig; van bouwen naar wonen, Den Haag: Staatsuitgeverij.

NEI (1989), Volkshuisvestingsbeleid in Europa, fase 1, beknopt overzicht van het beleid in een aantal geselecteerde landen, Rotterdam: NEI.

Nesslein, T.S. (1982), "The Swedish Housing Model: An Assessment", Urban Studies, pp, 235-246.

Pearsall, J. (1984), "France", in Wynn, M., (ed.), Housing in Europe, pp. 9-53, London: Croom Helm. 
Papa, O.A. (1992), Housing Systems in Europe: Part II. A Comparative Study of Housing Finance, (Housing and Urban Policy Studies 2) Delft: University Press.

Siksiö, O. (1993), "Stay and Pay, Privatisation of Housing and the Consumer, the Swedish Rental Case", Netherlands Journal of Housing and the Built Environment (8), no. 3, pp. 255-281.

Schaar, J. van der (1987), Groei en bloei van het Nederlandse volkshuisvestingsbeleid, Delft: Delftse Universitaire Pers.

Short, J.R. (1982), Housing in Britain; the Post-war Experience, London/New York: Methuen.

Smith, R. (1984), "Great Britain", in Wynn, M., Housing in Europe, London: Croom Helm.

Tham (1987), "Country Report: Sweden, A Personal View of Housing in an Aged Society, the Case of Sweden", paper presented at the International Conference on Finance \& Tax for Housing, October 21-22, 1987.

Trollegaard, S. (1989), Distributional Aspects of Housing and Taxation Policies, Model Monograph, prepared by the delegation of Denmark, United Nations.

United Nations (several years), Annual Bulletin of Housing and Building Statistics for Europe, New York: United Nations.

Westergard, K. (1989), Social Housing Policy, Denmark, Brussels: COFACE Housing Commission Documents. 